\title{
SEVERE SEPSIS - CLINICAL MANIFESTATIONS AND PHARMACO-ECONOMIC ANALYSIS IN AN INTENSIVE CARE UNIT IN LATVIA
}

\author{
Linda Brīdiṇa $^{1, \#}$, Angelika Krūmiṇa ${ }^{2}$, Oḷegs Šuba ${ }^{3}$, Vinita Cauce ${ }^{4}$, Indulis Vanags ${ }^{5}$, \\ and Ludmila Vïksna ${ }^{\circ}$ \\ ${ }^{1}$ Faculty of Continuing Education, Rīga Stradiṇš University, Dzirciema iela 16, Rīga, LV1007, LATVIA; \\ linda.bridina@gmail.com \\ ${ }^{2}$ Department of Infectology and Dermatology, Rīga Stradiṇš University, Dzirciema iela 16, Rīga, LV1007, LATVIA; \\ krumina.angelika@inbox.Iv \\ ${ }^{3}$ Rīga East Clinical University Hospital, Hipokrata iela 2, Rīga, LV1038, LATVIA; \\ olegs.suba@aslimnica.Iv \\ ${ }^{4}$ Department of Physics, Rīga Stradinš University, Dzirciema iela 16, Rīga, LV1007, LATVIA; \\ vinita.cauce@rsu.Iv \\ ${ }^{5}$ Department of Anaesthesiology and Reanimatology, Rīga Stradinš University, Pilsoṇu iela 13, Rīga, LV-1002, LATVIA; \\ Indulis.vanags@rsu.Iv \\ ${ }^{6}$ Department of Infectology and Dermatology, Rīga Stradiṇš University, Dzirciema iela 16, Rīga, LV1007, LATVIA; \\ ludmila.viksna@rsu.Iv \\ \# Corresponding author
}

Contributed by Ludmila Vïksna

Sepsis is widespread among hospitalised patients worldwide. In fact, severe sepsis and septic shock is a major cause of patient admission and mortality in intensive care units and the difficulty in diagnosing the initial stage of the disease is a major obstacle to the reduction of mortality from sepsis. Retrospective analysis of medical records of 72 patients was carried out within the framework of the study. The study included patients of both sexes and all ages, who were hospitalised at the stationary "Gailezers" of the Riga East Clinical University Hospital from 2011 to 2014. The study aim was to determine the clinical course of treated septic patients and conduct a pharmaco-economic analysis. In the course of the disease, almost half of the patients - 34 (48.6\%) showed development of septic shock. Mortality in these patients exceeded a half $(60.0 \%$; 21 patients). Artificial lung ventilation during hospitalisation was received by 43 (59.7\%) of patients. Artificial lung ventilation had been required in a significantly larger number of cases in the dead patient group $(75 \%, p=0.01)$. The average costs per one patient day (including bed-day price and manipulation costs) was 383 euros. Septic shock was associated with high mortality. Severe sepsis is an expensive diagnosis, as the average cost of one patient exceeds costs of other departments by 4.5 times.

Key words: septic shock, antibiotic therapy, Surviving Sepsis Campaign guidelines, sepsis mortality.

\section{INTRODUCTION}

Sepsis is a global problem and carries a high risk of mortality. Studies have shown that more than one-third of sepsis patients treated in an intensive care unit die. The primary cause of death due to infection is sepsis, despite the advances made in medicine, such as vaccination, antibacterial treatment options, and acute patient care.

A. Kumar's survey shows that each hour without antibacterial therapy for patients with septic shock increases mortal- ity by $7.6 \%$ (Kumar et al., 2006). When a patient enters the emergency department with severe sepsis diagnosis, the risk of mortality for the patient is 6 to 10 times greater than in those with acute myocardial infarction.

The number of patients hospitalised with sepsis has exceeded the number of cases of myocardial infarction (Yeh et al., 2010). Also, the number of death cases of sepsis exceeds the total number of death cases due to prostate cancer, breast cancer, and the acquired immune deficiency syndrome (AIDS). 
The increase in incidence of sepsis might be due to poor socio-economic conditions, greater awareness of the diagnosis, its detection, aging of the population, and the presence of chronic diseases. A great role is played by surgical intervention, widely useable invasive procedures, immunosuppressive and chemotherapeutics, and the expansion of microorganisms resistant to anti-bacterial therapy.

Sepsis is also one of the most expensive diagnoses in the world, representing a significant health burden; the annual costs in the USA in 2011 were more than 20 billion dollars. And the costs are rising on average by $11.9 \%$ each year (Torio and Andrews, 2011). In Germany, the average direct costs/patient amounted to 27467 euros; the total costs are estimated at approximately 7.7 billion euros. In the United States it is estimated that early diagnosis of sepsis and evidence-based therapy could reduce the number of deaths by 92000 per year and reduce hospital costs by more than 1.5 billion (Shorr et al., 2007).

The aim of the study was to determine the clinical course of treated septic patients and conduct a pharmaco-economic analysis.

\section{MATERIALS AND METHODS}

Retrospective analysis of medical records of 72 patients was carried out, stratified by year of treatment outcome (dead/alive). The study included both sexes and all ages of patients who were hospitalised at the Riga East Clinical University Hospital "Gailezers" in the period 2011 to 2014. All patients involved in the study had severe sepsis and at least one organ dysfunction. In all cases the included medical history was validated.

The patient costs were calculated according to data obtained by the Statistics Department of the Riga East Clinical University Hospital "Gailezers", which included the price of bed days and manipulation costs. The bed-day price was calculated according to the therapeutic department rate of 57 euros per one bed-day/24 hours. However, on average one patient of 72 patients involved in the study spent 9.4 days in the intensive therapy unit (sepsis clinic), where the price of one bed-day is 259 euros. Therefore, the standard bed-day price should be multiplied by at least 4.5 . The bedday price includes the necessary medication minimum set by Regulation No. 220 of the Cabinet of Ministers of the Republic of Latvia (Anonymous, 2007).

The medication costs were calculated from the medical records of each patient, which documented medication received at the sepsis clinic. The medication costs were obtained from the closed-type pharmacy Rìga East Clinical University Hospital "Gailezers".

The research has been carried out with the approval of the Ethics Committee of the Rìga East Clinical University Hospital "Gail,ezers".
Statistical methods. Data was described using means with standard deviations (SD) and median with interquartile range (IQR) for continuous variables and percentages for categorical variables. Non-parametric methods were used for the comparison of data: Mann-Whitney $U$ for continuous data and chi-square tests for categorical data. A $p$ value less than 0.05 was accepted as statistically significant. The statistical analysis was conducted using the SPSS (Statistical Package for the Social Sciences) (22.0 version) software.

\section{RESULTS}

Of the patient group, 40 (55.6\%) were men and 32 (44.4\%) were women. The age of patients ranged from 22 to 90 . Patient data on admittance to the main hospital are summarized in Table 1.

Distribution of age groups is given in Figure 1. The average age was 63.4 years (Table 1).

The average duration of patient illness and hospitalisation time was 5.6 days or median 3.0 (IQR 2.0 to 5.0) days (Table 1).

In the prehospital stage, no patients had received antibiotic therapy.

Average procalcitonine levels at admittance to the hospital was $35.4 \mathrm{ng} / \mathrm{ml}$, and only 3 (4\%) patients had a normal level (norm 0 to $0.05 \mathrm{ng} / \mathrm{ml}$ ).

Upon admittance to the hospital, the procalcitonine rate for patients who died was greater than in the survivors, respectively, $44.5 \mathrm{ng} / \mathrm{ml}$ and $29.1 \mathrm{ng} / \mathrm{ml}(p=0.018)$. (Fig. 2)

The average duration of treatment at the sepsis clinic was 9.4 days; median 7.5 (IQR 4.0 to 13.8 ) days. The clinical course of severe sepsis patients is summarised in Table 2 .

Respiratory system dysfunction was the most common (48 patients, 66.3\%), followed by renal dysfunction (25 pa-

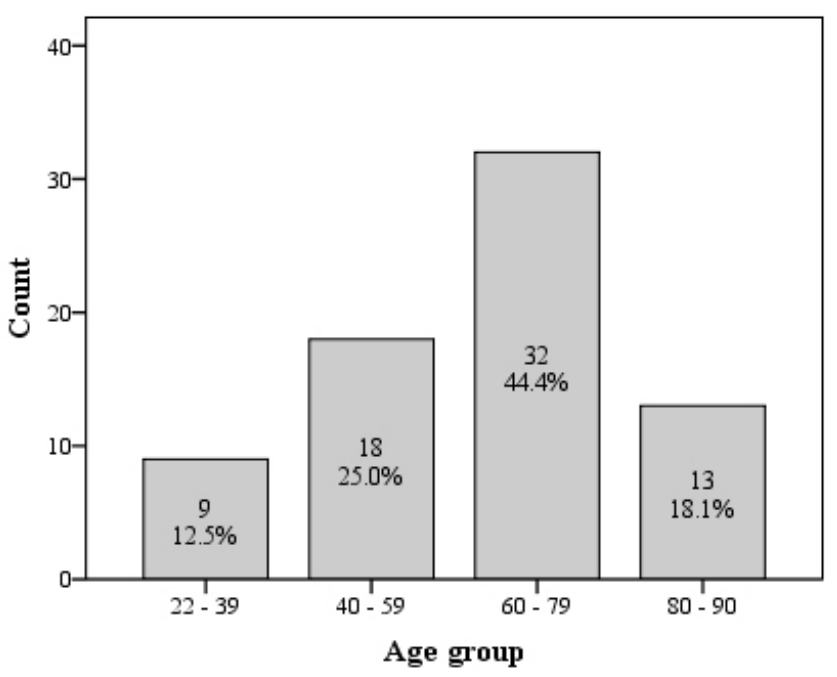

Fig. 1. Severe sepsis development in relation to age. 
PATIENT DATA IN THE EVENT OF A HOSPITAL

\begin{tabular}{|c|c|c|c|c|}
\hline \multirow[b]{2}{*}{ Parameter } & \multirow{2}{*}{$\begin{array}{l}\text { Total } \\
\mathrm{n}=72\end{array}$} & \multicolumn{2}{|c|}{ Treatment outcome } & \multirow[b]{2}{*}{$p$} \\
\hline & & $\begin{array}{c}\text { dead } \\
\mathrm{n}=36\end{array}$ & $\begin{array}{c}\text { alive } \\
\mathrm{n}=36\end{array}$ & \\
\hline \multicolumn{5}{|c|}{ Send to the hospital, n (\%) } \\
\hline medical emergency & $65(90.3 \%)$ & $34(52.3 \%)$ & $31(47.7 \%)$ & \multirow{2}{*}{0.429} \\
\hline referral & $7(9.7 \%)$ & $2(28.6 \%)$ & $5(71.4 \%)$ & \\
\hline men & $40(55.6 \%)$ & $17(42.5 \%)$ & $23(54.5 \%)$ & \multirow{2}{*}{0.155} \\
\hline women & $32(44.4 \%)$ & $19(59.4 \%)$ & $13(40.6 \%)$ & \\
\hline \multicolumn{5}{|l|}{ Age, years } \\
\hline average (SD) & $63.4(15.9)$ & $67.8(14.4)$ & $59.0(16.3)$ & \multirow{2}{*}{0.012} \\
\hline median (IQR) & $65.0(56.0-75.0)$ & $72.0(60.3-78.8)$ & $58.5(49.0-71.7)$ & \\
\hline average (SD) & $5.6(8.2)$ & $7.0(11.0)$ & $4.2(3.0)$ & \multirow{2}{*}{0.864} \\
\hline median (IQR) & $3.0(2.0-5.0)$ & $3.0(2.0-5.0)$ & $4.0(2.0-5.0)$ & \\
\hline \multicolumn{5}{|c|}{ Procalcitonine occurrence, $\mathrm{ng} / \mathrm{ml}$} \\
\hline average(SD) & $35.4(49.8)$ & $43.3(51.8)$ & $27.5(47.2)$ & \multirow{2}{*}{0.018} \\
\hline median(IQR) & $16.0(4.4-42.4)$ & $23.9(6.9-59.4)$ & $12.5(1.0-36.2)$ & \\
\hline
\end{tabular}

SD, standard deviation IQR,

interquartile range

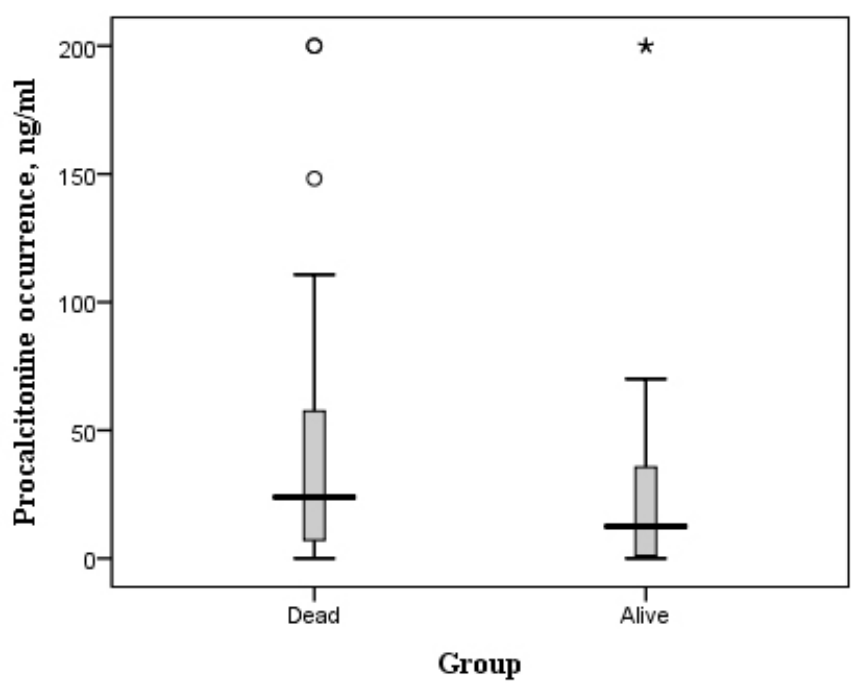

Fig. 2. Procalcitonine concentration in association with the outcome of the disease.

tients, 34.4\%). This organ dysfunction developed in the intensive care unit.

Artificial lung ventilation during hospitalisation was received by $43(59.7 \%)$ of patients, and the renal replacement therapy by $13(18.1 \%)$ patients. Both mechanical ventilation and renal replacement therapy were needed for 11(15.2\%) patients. In the dead patient groups, artificial lung ventilation was required significantly more cases, $(75 \%, p=0.01)$; renal replacement therapy was received by $25 \%(p=0.12)$ (Table 2).

Septic shock was observed in $34(48.6 \%)$ patients and 21 $(60.0 \%)$ of them died (Table 2$)$.

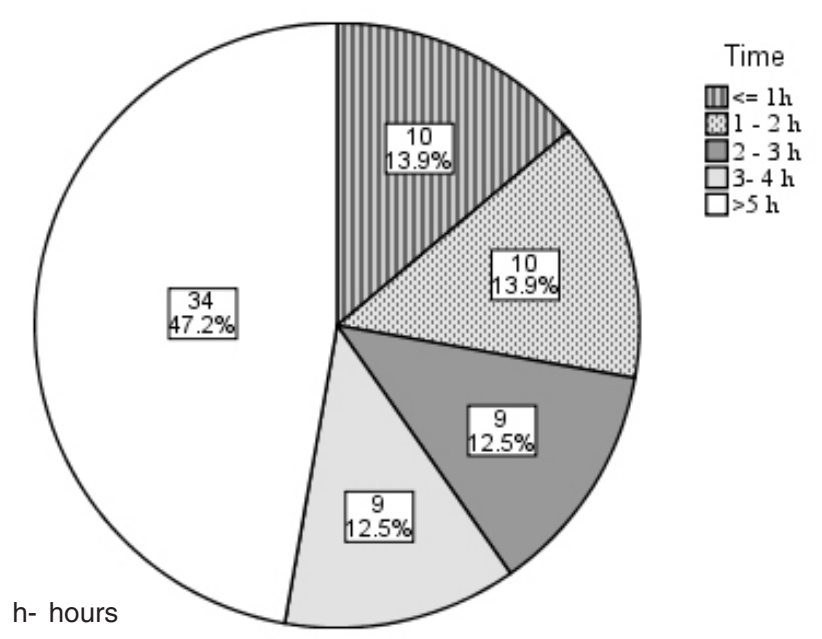

Fig. 3. Antibacterial therapy start-up time (h) since admittance to the stationary.

Microbiological plating of urine was positive in 11 (15.3\%) patients; the most common agents in plating was E. coli and Staphylococci. Plating of blood was positive in 32 (44.4\%) patients. The Streptococcus pneumoniae Ag test was positive in $17(23.6 \%)$ patients (Table 2).

During the first hour of admittance in the hospital, antimicrobial therapy was received by $10(13.9 \%)$ of the patients (Fig. 3). Among patients receiving antibiotic therapy after 5 hours, 19 (55.9\%) died (Fig. 4).

The most common final clinical diagnosis was pneumonia (34 patients, $47.2 \%$ ), followed by intra-abdominal infection (16 patients, $22.2 \%$ ), sepsis of unspecified aetiology (6 patients, $8.3 \%$ ), complex soft tissue infections (5 patients, 


\begin{tabular}{|c|c|c|c|c|}
\hline \multirow[b]{2}{*}{ Parameter } & \multirow[b]{2}{*}{$\begin{array}{l}\text { Total } \\
\mathrm{n}=72\end{array}$} & \multicolumn{2}{|c|}{ Treatment outcome } & \multirow[b]{2}{*}{$p$} \\
\hline & & $\begin{array}{c}\text { dead } \\
\mathrm{n}=36\end{array}$ & $\begin{array}{c}\text { alive } \\
\mathrm{n}=36\end{array}$ & \\
\hline \multicolumn{5}{|c|}{ The number of bed days ITU (sepsis clinic) } \\
\hline average(SD) & $9.4(6.9)$ & $9.9(8.5)$ & $9.0(4.8)$ & \multirow{2}{*}{0.607} \\
\hline median (IQR) & $7.5(4.0-7.5)$ & $7.0(2.0-16.5)$ & $8.0(5.0-11.5)$ & \\
\hline \multicolumn{5}{|c|}{ Artificial lung ventilation, n (\%) } \\
\hline yes & $43(59.7 \%)$ & $27(62.8 \%)$ & $16(37.2 \%)$ & \multirow{2}{*}{0.008} \\
\hline no & $29(40.3 \%)$ & $9(31.0 \%)$ & $20(69.0 \%)$ & \\
\hline \multicolumn{5}{|c|}{ Artificial lung ventilation, days } \\
\hline Average(SD) & $7.4(7.4)$ & $8.2(8.6)$ & $6.1(4.8)$ & \multirow{2}{*}{0.830} \\
\hline median (IQR) & $6.0(2.0-12.0)$ & $6.0(2.0-12.0)$ & $5.5(2.3-8.5)$ & \\
\hline \multicolumn{5}{|c|}{ Renal replacement therapy, n (\%) } \\
\hline yes & $13(18.1 \%)$ & $9(69.2 \%)$ & $27(45.8 \%)$ & \multirow{2}{*}{0.126} \\
\hline no & $59(81.9 \%)$ & $4(30.8 \%)$ & $32(54.2 \%)$ & \\
\hline \multicolumn{5}{|c|}{ Renal replacement therapy, days } \\
\hline average(SD) & $3.1(1.7)$ & $2.9(1.6)$ & $3.6(1.9)$ & \multirow{2}{*}{0.518} \\
\hline median (IQR) & $3.0(1.8-5.0)$ & $3.0(1.5-4.0)$ & $5.0(1.5-5.0)$ & \\
\hline \multicolumn{5}{|l|}{ Septic shock, $\mathrm{n}(\%)$} \\
\hline yes & $35(48.6)$ & $21(60.0 \%)$ & $14(40.0 \%)$ & \multirow{2}{*}{0.099} \\
\hline no & $37(51.4)$ & $15(40.5 \%)$ & $22(59.5 \%)$ & \\
\hline \multicolumn{5}{|c|}{ Plating of urine, $\mathrm{n}(\%)$} \\
\hline positive & $11(15.3)$ & $4(36.4 \%)$ & $7(63.6 \%)$ & \multirow{2}{*}{0.326} \\
\hline negative & $61(84.7)$ & $32(52.5 \%)$ & $29(47.5 \%)$ & \\
\hline \multicolumn{5}{|l|}{ Blood plating $\mathrm{n}(\%)$} \\
\hline positive & $32(44.4)$ & $15(46.9 \%)$ & $21(52.5 \%)$ & \multirow{2}{*}{0.635} \\
\hline negative & $40(55.6 \%)$ & $17(53.1 \%)$ & $19(47.5 \%)$ & \\
\hline \multicolumn{5}{|c|}{ Streptococcus pneumonia $\mathrm{Ag}$ test, $\mathrm{n}(\%)$} \\
\hline positive & $17(23.6 \%)$ & $8(47.1 \%)$ & $9(52.9 \%)$ & \multirow{2}{*}{0.781} \\
\hline negative & $55(76.4 \%)$ & $28(50.9 \%)$ & $27(49.1 \%)$ & \\
\hline \multicolumn{5}{|l|}{$\mathrm{A} / \mathrm{b}$ initiation, hours } \\
\hline average(SD) & $8.2(21.8)$ & $9.1(20.3)$ & $4.6(7.8)$ & \multirow{2}{*}{0.564} \\
\hline median (IQR) & $3.5(1.7-5)$ & $4.0(2.0-5.0)$ & $12.5(1.0-36.2)$ & \\
\hline
\end{tabular}

$\mathrm{SD}$, standard deviation

$\mathrm{IQR}$, interquartile range

$\mathrm{A} / \mathrm{b}$, antibacterial therapy

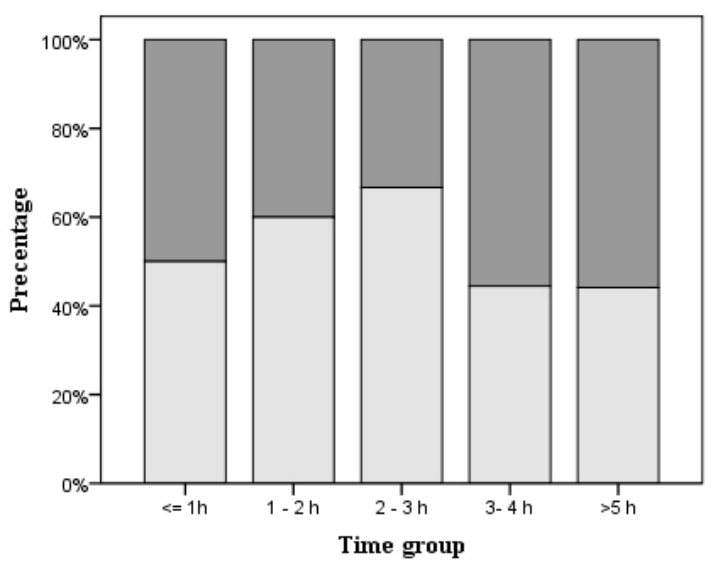

Fig.4. Antibacterial therapy in association with mortality.
$7.0 \%$ ), tumour ( 3 patients, $4.2 \%$ ), endocarditis ( 3 patients, 4. $2 \%$ ), meningoencephalitis ( 3 patients, $4.2 \%$ ), and urinary tract infection (2 patients, $2.7 \%)$.

According to data obtained by the Statistics Department of the Riga East Clinical University Hospital "Gailezers" the total costs for 72 patients was 160236 euros which included 71494 euros for bed-day price, manipulation costs of 70742 euros and medication costs of 18000 euros.

The average hospitalisation costs per patient were 2226 (SD 1830) euros, which included 993 (SD 772) euros for beddays, manipulation costs of 983 (SD 1179) euros and medication costs of 250 euros.

We did not find any significant association between cost and survival (Fig. 5). 


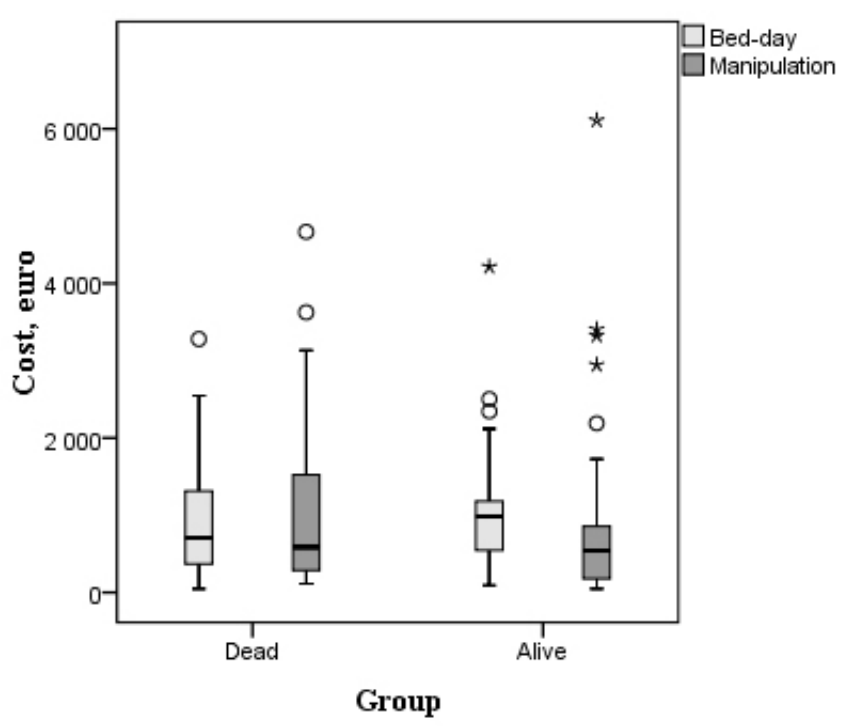

Fig. 5. Costs associated with antibacterial therapy outcome.

The average costs for a one patient day (included bed-day price and manipulation costs) was 383 euros, median 198 (IQR 136 to 378).

\section{DISCUSSION}

Sepsis is one of the most frequent reasons for hospitalisation in intensive care units worldwide. Early sepsis detection and timely treatment administration with appropriate antibiotics are the most important factors in improving the outcome of sepsis. However, the initial sepsis clinical signs and symptoms are non-specific, creating the risk of late diagnosis.

Epidemiology. In all countries where the registration of hospital sepsis patients exists, the number is growing. Sepsis is a serious clinical condition resulting from severe infections. In the United States, the annual incidence of sepsis was reported to be 750000 cases in 2005 and over 1665000 cases were reported with high mortality rates as high as 20 to 50 per cent in 2009. In Spain the incidence of severe sepsis and septic shock is 104/100 000 adults and $31 / 100000$ adults per year with $20.7 \%$ and $45.7 \%$ hospital mortality, respectively. In the Netherlands, 15500 cases with severe sepsis and 6000 patients with the septic shock were admitted to hospitals annually. In Asia, in Taiwan a severe sepsis incidence rate was reported - 507/1000 with $45 \%$ mortality in 2008. In German hospitals, in the period 2007-2013, sepsis incidence increased by overall 5.7\% annually from 200535 to 279530 cases. Mortality was $24.3 \%$, resulting in 67849 deaths per year. Sepsis now ranks third among the causes of deaths in Germany. Sepsis is diagnosed in $1.54 \%$ of hospital admissions (Reinhart, 2015). In China (2010), the sepsis mortality rate was 67.5 deaths per 100000 population, its ranks fourth among the causes of deaths in China (Bin, 2015).

Surviving Sepsis Campaign. The Surviving Sepsis Campaign (SSC) is an international programme that develops guidelines to improve the management of this serious clinical condition and to reduce the high mortality rates. The first SSC guidelines, which were published in 2004, classified the recommendations as a resuscitation bundle including elements for first six hours, and a resuscitation and management bundle including elements for first 24-hour management. The guidelines were renewed in 2008. Many studies revealed that clinical implementation of these bundle elements improve the quality of sepsis care and reduce hospital mortality. In 2012, the SSC 2008 guidelines were updated, and again in 2015; recommendations were classified as ones to be completed within three hours and others to be completed within six hours (Tufan et al., 2015). Of note, the 6-hour bundle was updated; the three-hour SSC bundle was not changed.

Elements to be implemented within three hours since the time of presentation were:

\section{Measure lactate level;}

2. Obtain blood cultures prior to administration of antibiotics;

\section{Administer broad spectrum antibiotics;}

4. Administer $30 \mathrm{ml} / \mathrm{kg}$ crystalloid for hypotension or lactate $\geq 4 \mathrm{mmol} / \mathrm{L}$.

The time of presentation is defined as the time of triage in the emergency department or, if presenting from another care venue, from the earliest chart annotation consistent with all elements of severe sepsis or septic shock ascertained through chart review.

Elements to be implemented within six hours since the time of presentation were:

5. Apply vasopressors (for hypotension that does not respond to initial fluid resuscitation) to maintain a mean arterial pressure $(\mathrm{MAP}) \geq 65 \mathrm{mmHg}$;

6. In the event of persistent hypotension after initial fluid administration (MAP $65 \mathrm{~mm} \mathrm{Hg}$ ) or if initial lactate was $\geq 4$ $\mathrm{mmol} / \mathrm{L}$, re-assess volume status and tissue perfusion and document reassessment of volume status and tissue perfusion with: Repeat focused exam (after initial fluid resuscitation) by licensed independent practitioner including vital signs, cardiopulmonary, capillary refill, pulse, and skin findings. Or two of the following: measure central venous pressure (CVP), measure central venous oxygen saturation (ScvO2), bedside cardiovascular ultrasound, dynamic assessment of fluid responsiveness with passive leg raise or fluid challenge;

7. Re-measure lactate if initial lactate elevated (Dellinger et al., 2012; Anonymous, 2014; Levy et al., 2014; Yealy et al., 2014; Mouncey et al., 2015).

Several studies show that, consistent with the guidelines, early initiation of antimicrobial therapy has reduced the duration of hospitalisation of patients and limited the develop- 
ment of resistance to antibiotics (Angus and van der Poll, 2013; Van den Bosch et al., 2014).

Our study showed that mean antimicrobial therapy start-up time from admittance to the hospital was 8.2 (SD 21.8) hours. During the first hour after admittance to the hospital, antimicrobial therapy was received by $10(13.9 \%)$ of the patients. The gold standard according to the guidelines is the initiation of antimicrobial therapy within one hour from the moment of diagnosing severe sepsis. It should be taken into account that at the time of hospitalisation, sepsis was not developed or proven in all of the patients, since by definition, diagnosis of sepsis is based on a number of physiological indicators and the results of laboratory investigations, as well as the identification of the focuses of infection that caused these modifications. Early initiation of antimicrobial therapy reduces bacterial load and hence the mortality of septic patients.

The role of micro-organisms. Respiratory tract infections, in particular pneumonia, are a major cause of the sepsis, and it is related to higher mortality. Our data showed that in patients with pneumonia $(34.5 \%)$, the mortality rate was $55.9 \%$ (19 patients). Currently, gram-positive microorganisms more frequently suggest sepsis than gram-negative microorganisms. However, a large meta-analysis study reported that gram-negative bacteraemia is associated with higher mortality than gram-positive bacteraemia. Coagulase-negative Staphylococcus and E. coli were most commonly found in the bloodstream, and were associated with a low mortality rate $(20 \%$ and $19 \%)$, in comparison with Candida species, where the mortality rate was $43 \%$ and Acinetobacter species $40 \%$. However, pneumoniae caused by Staphylococcus aureus is associated with higher mortality $(41 \%)$, in comparison with pneumonia caused by Streptococcus pneumonia (13\%). The highest mortality was associated with Pseudmonas aeruginosa (77\%). However, more than a half of blood culture from patients with severe sepsis were not positive (Cohen et al., 2004). In our study, 55.6\% of cases were negative on bacterial plating of blood.

Studies have indicated that older patients, male gender, African Americans, and patients with chronic health problems are particularly prone to the development of severe sepsis, and therefore prevention strategies should be targeted to these groups (Mayr et al., 2014). Our data showed that most of the patients were in the age group of 60 to 79 ( $\mathrm{n}=$ $32.4 \%$ ) and $20(62.5 \%)$ died. Severe sepsis occurs more often in patients with chronic obstructive pulmonary disease, tumours, chronic kidney, liver diseases, and diabetes. Other risk factors that increase the risk of developing sepsis are long-term care at care establishments, malnutrition, use of immunosuppressive medications, and immunocompromised patients. There have also been reports on the relationship between socioeconomic status and blood stream infection (Mendu et al., 2012).

Causes of the severe sepsis and their relative frequency. The most common cause of sepsis is pneumonia (50 to 60\% of patients, which is comparable to our data -34 patients,
47.2\%; 95\% CI (confidence interval) $36.1 \%$ to $58.6 \%$ ), intra-abdominal infections are found in 20 to $25 \%$ (our data - 16 patients, $22.2 \%$; $95 \%$ CI $14,2 \%$ to $33.1 \%$ ), urinary tract infection in 7 to $10 \%$ (our data -2 patients, $2.7 \%$; $95 \%$ CI $0.7 \%$ to $10.0 \%$ ), soft tissue involvement, bones, joints in 5 to $10 \%$ (our data -5 patients, $7.0 \%$; $95 \%$ CI 3, $0 \%$ to $15,3 \%$ ), endocarditis in $\%$ (our data -3 patients, $4.2 \%$; $95 \%$ CI $1.4 \%$ to $11.6 \%$ ), and meningitis in $5 \%$ (our data -3 patients, $4.2 \%$; $95 \%$ CI $1.4 \%$ to $11.6 \%$ ) (Vincent et al., 2006). Similar results also were shown in the SOAP study (Sepsis Occurrence in Acutely Ill Patients), which was conducted among 198 intensive care units in 24 European countries; the most common infectious cause of sepsis patients was in the pulmonary system $(68 \%)$, followed by the localisations in the abdominal cavity $(22 \%)$, blood (20\%) and urinary tract (14\%) (Barochia et al., 2010).

Diagnostic options. Recently, a number of publications have shown that genetic variation, particularly single nucleotide polymorphism of cytokines in the innate immune system, may affect risk of sepsis. Among these cytokines, interleukin-6 (IL-6) is one of the most important members that may be associated with sepsis risk and outcome. Some studies have indicated that IL-6 may play a key role in the inflammatory response to microbial invasion (Gao et al., 2015).

Previous studies showed that a high IL-6 level was associated with increased severe sepsis mortality and risk (Palmiere and Augsburger, 2014).

Extensive investigations into the efficacy of lactate kinetics as a marker for response to resuscitative therapies in septic patients have demonstrated a clear association with clinical outcomes including mortality. However, the majority of studies have focused on the utility during the early phase of sepsis management, with little attention regarding later time periods. Future studies should focus on lactate as a potential prognostic tool for late sepsis management and treatment duration, as increased knowledge in this direction has the potential to direct physicians in their care for septic patients during this understudied time period and improve patient outcomes (Yeh et al., 2010).

Procalcitonine also may be associated with sepsis risk and outcome. Our study showed that procalcitonine concentration for the dead patients was greater than for the survivors.

The detection of early sepsis patients is very important. There are a variety of scales that can help to detect early septic patients, such as the modified early warning score (MEWS, Modified Early Warning Score) used for the evaluation of the patient. The criteria are based on evaluation of deviation from the physiological norm. This scale has demonstrated its importance as a screening method in sepsis / severe sepsis diagnostics. In Latvia such scales have not been introduced yet.

If the patient has 4 or more points according to the MEWS, or suspicion of infection, then the probability of the Sys- 
temic Inflammatory Response Syndrome (SIRS) should be considered and due to possible accession of sepsis the patient should be evaluated every 30 minutes to provide early diagnosis of possible sepsis (Zavatti et al., 2010). Application of this scale would be very useful in the outpatient prehospital stage, as well as at reception, as it would allow to differentiate the potential septic patients. However, there is need of further studies to introduce the following scales. They need to be easy to use and widely applicable before introduction.

A study limitation was the small number of patients, which made it difficult to assess the cost differences and effects of antibacterial treatment.

\section{REFERENCES}

Angus, D. C., van der Poll, T. (2013). Severe sepsis and septic shock. New Engl. J. Med., 369, 840-851.

Anonymous (2007). Regulations of the Cabinet of Ministers of the Republic of Latvia. Available at: http://likumi.lv/doc.php?id=155314\&from=off (in Latvian).

Anonymous (2014). Goal-directed resuscitation for patients with early septic shock. The ARISE Investigators and the ANZICS Clinical Trials Group. New Engl. J. Med., 371, 1496-1506.

Barochia, A. V., Cui, X., Vitberg, D., Suffredini, A. F., O'Grady, N. P., Banks, S. M., Minneci, P., Kern, S. J., Danner, R. L., Natansonm, C., Eichacker, P. Q. (2010). Bundled care for septic shock: An analysis of clinical trials. Crit. Care Med., 38 (2), 668-678.

Bin, Du. (2015). Surviving sepsis guidelines - revisited in China. World Wide Sepsis Webinar. Available at:

http://world-sepsis-day.org/wwsw/wwswview2015_BD_en.shtml (accessed 02.06.2016)

Chertoff, J., Chisum, M., Garcia, B., Lascano, J. (2015). Lactate kinetics in sepsis and septic shock: A review of the literature and rationale for further research. J. Intensive Care, 3, 39 .

Cohen, J., Cristofaro, P., Carlet, J., Opal, S. (2004). New method of classifying infections in critically ill patients. Crit. Care Med., 32, 1510-1526.

Dellinger, R. P., Levy, M. M., Rhodes, A. Annane, D., Gerlach, H., Opal, S. M., Sevransky, J. E., Sprung, C. L., Douglas, I.S., Jaeschke, R., Osborn, T.M., Nunnally, M. E., Townsend, S. R., Reinhart, K., Kleinpell, R. M., Angus, D. C., Deutschman, C. S., Machado, F. R., Rubenfeld, G. D., Webb, S. A., Beale, R. J., Vincent, J. L., Moreno, R. (2013). Surviving Sepsis Campaign: International guidelines for management of severe sepsis and septic shock: 2012. Crit. Care Med., 41, 580-637.

Gao, J. W., Zhang, A. G., Pan, W., Yue, C., Zeng, L., Gu, W., Jiang, J. (2015). Association between IL-6-174G/C polymorphism and the risk of sepsis and mortality: A systematic review and meta-analysis. PLoS One, 10 (3). e0118843. Available at:

http://www.ncbi.nlm.nih.gov/pmc/articles/PMC4348480/ (accessed 03.06.2016).

Kumar, A., Roberts, D., Wood, K. E., Light, B., Parrillo, J. E., Sharma, S., Suppes, R., Feinstein, D., Zanotti, S., Taiberg, L., Gurka, D., Kumar, A.,
Cheang, M. (2006). Duration of hypotension prior to initiation of effective antimicrobial therapy is the critical determinant of survival in human septic shock. Crit. Care Med., 34 (6), 1589-1596.

Levy, M. M., Rhodes, A., Phillips, G. S., Townsend, S. R., Schorr, C. A., Beale, R., Osborn, T., Lemeshow, S., Chiche, J. D., Artigas, A., Dellinger, R. P. (2014). Surviving Sepsis Campaign: Association between performance metrics and outcomes in a 7.5-year study. Intensive Care Med., 40 (11), 1623-1633.

Mayr, F. B., Yende, S., Angus, D. C. (2014). Epidemiology of severe sepsis. Virulence, 5 (1), 4-11.

Mendu, M. L., Zager, S., Gibbons, F. K., Christopher, K. B. (2012). Relationship between neighborhood poverty rate and bloodstream infections in the critically ill. Crit. Care Med., 40, 1427-1436.

Mouncey, P. R., Osborn, T. M., Power, G. S., Harrison, D. A., Sadique, M. Z., Grieve, R. D., Jahan, R., Harvey, S. E., Bell, D., Bion, J. F., Coats, T. J., Singer, M., Young, J. D., Rowan, K. M. (2015). Trial of early, goaldirected resuscitation for septic shock. New Engl. J. Med., 372 (14), 1301-1311.

Palmiere, C., Augsburger, M. (2014). Markers for sepsis diagnosis in the forensic setting: State of the art. Croat. Med. J., 55, 103-114.

Reinhart, K. (2015). Global impact of sepsis. World Wide Sepsis Webinar. Available at:

http://world-sepsis-day.org/wwsw/wwswview2015_KR_en.shtml (accessed 04.06.2016).

Shorr, A. F., Micek, S. T., Jackson, W. L. Jr., Kollef, M. H. (2007). Economic implications of an evidence-based sepsis protocol: Can we improve outcomes and lower costs? Crit. Care Med., 35 (5), 1257-1262.

Torio, C. M., Andrews, R. M. (2011). National Inpatient Hospital Costs: The Most Expensive Conditions by Payer. Healthcare Cost and Utilization Project (HCUP) Statistical Briefs. Available at:

https://www.hcup-us.ahrq.gov/reports/statbriefs/sb160.jsp (accessed 03.06.2016).

Tufan, Z. K., Eser, F. C., Vudali, E., Batirel, A., Kayaaslan, B., Bastug, A. T., Eray, D., Turhan, V., Duygu, F., Tok, D., Altun, S., Bulut, C. (2015). The knowledge of the physicians about sepsis bundles is suboptimal: A multicenter survey. J. Clin. Diagn. Res., 9 (7), OC13-OC16.

Van den Bosch, C. M. A., Hulscher, M. E. J. L., Natsch, S., Gyssens, I. C., Prins, J. M., Geerlings, S. E. (2014). Development of quality indicators for antimicrobial treatment in adults with sepsis. BMC Infect. Dis., 14, 345.

Vincent, J. L., Sakr, Y., Sprung, C. L., Ranieri, M., Reinhart, K., Gerlach, H., Moreno, R., Carlet, J., Le Gall, J., R., Payen, D. (2006). Sepsis in European intensive care units: Results of the SOAP Study. Crit. Care Med., 34 (2), 344-353.

Yealy, D. M., Kellum, J. A., Huang, D. T., Barnato, A. E., Weissfeld, L. A., Pike, F., Terndrup, T., Wang, H. E., Hou, P. C., LoVecchio, F., Filbin, M. R., Shapiro, N. I., Angus, D. C. (2014). A randomized trial of protocolbased care for early septic shock. New Engl. J. Med., 370 (18), 1683-1693.

Yeh, R. W., Sidney, S., Chandra, M., Sorel, M., Selby, J. V., Go, A. S. (2010). Population trends in the incidence and outcomes of acute myocardial infarction. New Engl. J. Med., 362 (23), 2155-2165.

Zavatti, L., Barbieri, E., Amateis, E., Girardis, M. (2010). Modified Early Warning Score and identification of patients with severe sepsis. Crit. Care., 14 (Suppl. 1), 254.

Received 2 November 2015 


\section{SMAGA SEPSE — KLĪNISKĀS IZPAUSMES UN FARMAKOEKONOMISKĀ ANALĪZE INTENSĪVĀS TERAPIJAS NODALĀĀ LATVIJĀ}

Pētījuma mērḳis bija izvērtēt Rīgas Austrumu klīniskās universitātes slimnīcas stacionārā "Gaiḷezers" ārstēto septisko pacientu slimības gaitu un farmakoekonomisko analīzi. Tika veikta retrospektīva 72 pacientu slimību vēsturu analīze, stratifikācija tika veikta pēc terapijas gada un saslimšanas iznākuma. Pētījumā tika iekḷauti abu dzimumu un visu vecumu pacienti, kas tika stacionēti Rīgas Austrumu klīniskās universitātes slimnīcas stacionārā "Gaiḷezers" no 2011. līdz 2014. gadam. Visas pētījumā ieklautās slimības vēstures tika atzītas par derīgām. Pacientu izmaksas tika aprēḳinātas pēc Rīgas Austrumu klīniskās universitātes slimnīcas "Gailezers" iegūtajiem statistikas daḷas datiem. Dati tika aprakstīti, pielietojot standartnovirzes (SD) un mediāno ar starpkvartiḷu amplitūdu. Pētījuma datu salīdzināšanai izmantoja Mann-Whitney $U$ un chi-square testus. Datu statistiskā analīze tika veikta ar SPSS (22.0 versiju). Apkopojot rezultātus, biežākā pamatdiagnoze pacientiem bija pneimonija - 34 (47.2\%). Prehospitālā etapā antibakteriālo terapiju nebija saṇemis neviens pacients. Pirmās stundas laikā no stacionēšanas brīža antibakteriālo terapiju san̨ēma $10(13,9 \%)$ pacientu. Vairāk kā pusei pacientu 43 (59,7\%) bija nepieciešama mākslīgā plaušu ventilācija. Novēroja augstu mirstību - 21 (60, 0\%) — pacientiem ar septisko šoku (34; 48,6\%). Kopējās 72 pacientu izmaksas sastādīja 160236 eiro. Smaga sepse un septisks šoks ir biežs iemesls pacientu uzṇemšanai un mirstībai intensīvās terapijas nodạ̦ās. Tādēl ir ḷoti nozīmīga agrīna šo pacientu atklāšana un adekvātas terapijas uzsākšana. Sepse ir viena no dārgākajām diagnozēm pasaulē, kas veido nozīmīgu veselības aprūpes slogu. 